\title{
Elma Ağaçlarında Yaz Budamasının Meyve ve Yaprakların Kalsiyum İçeriği Üzerine Etkisi
}

\author{
Kadir UÇGUN* Mesut ALTINDAL Murat CANSU \\ Meyvecilik Araștırma Enstitüsü Müdürlüğü, Isparta
}

*Sorumlu yazar e-posta (Corresponding author e-mail): kadirucgun@gmail.com

DOI: 10.21657/topraksu.338309

\begin{abstract}
Öz
Vejetatif gelișmeyi teșvik eden herhangi bir uygulama meyvelerin Ca içeriğini olumsuz etkiler. Mevcut Ca'un kullanımında meyve ve vejetatif aksam arasında vejetatif aksam lehinde șiddetli bir yarıș vardır. Azot, P, Mg ve K iyonları floemde kolaylıkla tașınabilmesine rağmen Ca iyonu çok az ve yavaș tașınmakta ve yeni gelișen meristematik dokulara yapraklarda gerçekleșen transprasyon ile yani ksilem yolu ile ulașmaktadır. Kalsiyumun elma yapraklarında genellikle eksikliği görülmediği halde meyvelerde Ca eksikliğine sık rastlanmaktadır. Tohum anacı üzerine așılı tam verimdeki "Starkrimson Delicious" çeșidinde yapılan bu çalıșmada yaz budamasının yaprak ve meyvenin Ca içeriği üzerine etkisi araștııımıștır. Mayıs ayı sonlarında aynı yılın sürgünleri yaklașık $20 \mathrm{~cm}$ olduğunda yaz budaması yapıımıș ve Temmuz ayı bașında meyveler yaklașık $70 \mathrm{~g}$ olduğunda hem yapraklarda hem de meyvelerde Ca analizleri yapılarak uygulamalar karșılaștııılmıștır. Yaprakların Ca içeriği yaz budaması yapılan ağaçlarda $\% 1,29$; yapılmayanlarda ise \% 1,26 bulunmuș ve istatistiksel olarak önemli olmamıștır. Meyvelerde ise yaz budaması yapılan ve yapıımayan ağaçların Ca içeriği sırasıyla 59,47 ve 50,86 mg $100 \mathrm{~g}^{-1}$ olduğu tespit edilmiș ve istatistiksel olarak \%1 düzeyinde önemli bulunmuștur. Bu sonuçlar meyvenin Ca içeriğinin arttırımasında yaz budamasının önemini göstermektedir.
\end{abstract}

Anahtar Kelimeler: Elma, kalsiyum, yaz budaması

\section{The Effect of Summer Pruning on Calcium Content of Fruit and Leaves of Apple Trees}

\begin{abstract}
Any applications promoting vegetative growth effects adversely Ca content of fruit. There is a violent race between fruit and vegetative parts in the use of existing Ca and vegetative parts are more powerful in this race. Although nitrogen, $\mathrm{P}, \mathrm{Mg}$ and $\mathrm{K}$ can be transported easily in phloem, Ca ions are transported very small amounts and slowly. Calcium ions absorbing can be reached to meristematic tissue by the xylem or transpiration that occurring in leaves. Although Ca deficiency is not seen in apple leaves, it is seen commonly in the fruits. This study was carried out "Starkrimson Delicious" cultivar grafted onto seedling rootstocks and at full yield and it was investigated efficiency of summer pruning on Ca content of leaves and fruit. In late May, summer pruning was made when shoots of the same year were approximately $20 \mathrm{~cm}$ length. In early July, both leaves and fruit samples were collected when fruits were about $70 \mathrm{~g}$ and Ca contents were determined and the applications were compared in terms of Ca and the other nutrients. While Ca content of leaves were $1.29 \%$ in summer pruning, $1.26 \%$ in not summer pruning and not statistically significant. In fruit, Ca content were $59.47 \mathrm{mg} 100$ $\mathrm{g}^{-1}$ in summer pruning, $50.86 \mathrm{mg} 100 \mathrm{~g}^{-1}$ in not summer pruning and it was found that the results were significant statistically at the $1 \%$ level. These results demonstrate the importance of summer pruning to increase the Ca content of fruit.
\end{abstract}

Key Words: Apple, calcium, summer pruning 


\section{Gíris}

Kalsiyum (Ca) diğer bitki besin elementlerine göre yer kabuğunda daha yaygın ve daha fazla bulunur. Yer kabuğunun yaklașık \%3,50'si Ca'dur. Kalsiyum kapsamı yönünden topraklar arasında büyük farklılıklar vardır. Tekstürleri ne olursa olsun kurak yöre topraklarının Ca kapsamları yüksektir. Bunun nedeni yağıșın ve dolaysıyla yıkanmanın az olmasıdır. Kurak yörelerdeki çoğu topraklar, profilleri arasında kalsiyum karbonatya da kalsiyum sülfat birikintilerine sahiptir (Kacar, 1995).

Kalsiyum, bitkiler tarafindan $\mathrm{Ca}^{+2}$ iyonu șeklinde alınır ve bitkiler için zorunlu bir element olan $\mathrm{Ca}^{+2}$ bitki bünyesinde inorganik tuzlar, organik asitler, plazma kolloidlerine tutulmuș șekilde ve immobilize edilmiș șekilde bulunur. Kalsiyum diğer maddelerle birlikte bitki dokularının yapısal ve fizyolojik stabilitesinde görev alır (Bergmann, 1992). Elmalarda Ca'un yetersiz seviyeleri yapraklardan daha çok meyvelerde olușur. Yapraklarda eksiklik belirtileri bahçelerde nadiren görülür fakat düșük Ca ile beslenen ağaçlarda eksiklik belirtileri tanımlanabilir. Kalsiyum eksikliği en genç sürgün yapraklarının yukarıya doğru fincan șeklinde kıvrılması, daha sonra damarsal ve damar aralarında kloroz gelișimi, sonuç olarak yaprak kenarlarında nekrotik dokular ve klorotik benek gelișimi olarak tanımlanmıștır. Meyve üzerindeki belirtiler çok daha belirgin olmaktadır ve anormal kabuk bronzlașması, geç sezonda lentisellerin koyulașması ve bazı zaman hasatta șiddetli meyve çatlaması ile kendini gösterir. Yetersiz Ca, sebze ve meyvelerde depolarda birçok fizyolojik bozuklukları ortaya çıkarmaktadır. Örneğin elmalarda Acıbenek, Çatlama, İc Kararması, Jonathon Spot, Lentisel Blotch, İ ș Sulanması ve Düșük Sıcaklık ve Yașlanma bozulmaları Ca eksikliğinde ortaya çıkan fizyolojik bozukluklardır (Neilsen ve Neilsen, 2003). Perring vd. (2006), Lentisel Blotch ve/ veya İç Sulanması görülen bahçelerden aldıkları meyvelerde Ca içeriklerinin çok düșük olduğunu tespit etmișler ve özellikle depolama esnasında Lentisel Blotch șiddetinin Ca konsantrasyonun düșmesi ve/veya K konsantrasyonunun artması ile arttığını tespit etmișlerdir. Ayrıca aynı yerden alınan meyvelerde görülen çatlamanın da bu etmenlerden olduğu belirlenmiștir. Çalıșma sonucunda Ca nedenli fizyolojik bozukluklar Ca miktarı meyvede taze ağırlık üzerinden 40 ppm'in altına düștüğünde görülmüștür. Kadir (2004), $\mathrm{CaCl}_{2}$ uygulamalarının meyve kalitesini arttırdığını fakat Ca uygulamaları yapılan ağaçlarda kontrol uygulamalarına göre $\mathrm{N}, \mathrm{P}, \mathrm{K}$ ve Mg içeriğinin de yüksek olduğu tespit edilmiștir. Bu elementlerde Ca gibi meyve kalitesini etkilemektedir. Bu bilgiler ıșığında $\mathrm{CaCl}_{2}$ uygulamaları besin elementleri arasındaki dengeleri değiștirerek meyve kalitesini iyileștirdiği düșünülmektedir.

Yumușak çekirdekli meyvelerde hasat sonrası meyve kalitesini etkileyen hasat öncesi șartların çoğu, kültürel uygulamalar ve iklim olmak üzere iki kategoriye ayrılır. Anaç/ağaç yașı, sulama ve gübreleme uygulamaları, budama ve terbiye sistemleri, ürünyükü/meyve büyüklüğü, tozlașma/ tohum sayısı, kimyasal yaprak uygulamaları ve gelișim düzenleyicileri kültürel uygulamalar arasında yer almaktadır. İklim faktörlerini ise sıcaklık (sezonal ve hasat öncesi), ıșı (kalite, yoğunluk ve süre) ve toprak suyu olușturmaktadır (Bramlage, 1993). Kalsiyum eksikliği hücre içi nitrit tașınımını bozduğu için nitrit $\left(\mathrm{NO}_{2}{ }^{-}\right)$birikimine neden olur. Bu yüzden Ca eksikliği olan bitkiler azot kaynağı olarak etkili bir șekilde nitratları kullanamazlar (Bergmann, 1992).

Bitki besleme açısından Ca ile diğer besin elementleri arasında önemli ilișkiler bulunmaktadır. Bu ilișkiler olumlu ya da olumsuz olabilmektedir. Bor ve Ca arasında da yakın bir ilișki bulunmaktadır. B'un özellikle meyveye Ca'un tașınmasında önemli bir görevi vardır ve bu yolla "Corking" olușumunu önler veya azaltır. Normal hücre gelișimi ve farklılașması için her iki iyonun da yeterli miktarda bulunmasına intiyaç vardır. Bazen bu iki iyonun eksiklik belirtileri birbirine benzemektedir. Özellikle B ve Ca eksikliklerinin beraber oluștuğu bozukluklarda teșhis çok zor olmaktadır. Așırı derecede Ca uygulanması B alınımını engellemektedir (Bergmann, 1992). Kalsiyum ve $\mathrm{K}$ arasındaki etkileșim ise meyvelerde en çok rastlanan olaylardan biridir. Meyvedeki K: Ca oranı sonbaharda Acıbenek ve diğer fizyolojik hastalıklar olușup olușmayacağının önemli bir göstergesi olarak tespit edilmiștir (Drahorad, 1999). Dilmaghani vd. (2004), yaptıkları çalıșmada meyvedeki Ca ile meyve eti sertliğinin arttığını ancak hasatta meyvelerdeki K:Ca oranı artması ile meyve setliğinin azaldığını tespit etmișlerdir. Çalıșma sonucunda yapraklardaki K:Ca oranı 0,9-1,4; meyvede ise 19-46 arasında değiștiğini belirtmișlerdir. 
Yapraktaki Ca \%1,3-2,0 arasında olduğunda yeterli kabul edilir (Hoying vd., 2004). Elma ağaçlarında yaprak analizleri genellikle daha yüksek miktarlarda Ca intiyacı olduğunu göstermektedir. Elma ağaçları topraktan Ca'un alınması ve özellikle yaprak ve meyvelere tașınmasında çok etkili değildir. Hoying vd. (2004)'nın da belirttiği gibi kuraklık șartlarında meyvedeki Ca yapraklara tașınmaktadır. Bu nedenle meyvelerin Ca içeriğini arttırmak için yaprak gübrelemesi, hatta direk meyve üzerine yaprak gübrelerinin uygulanması ve meyvelerin Ca çözeltilerine daldırıması gibi uygulamalar yapılmaktadır. Topraktan Ca uygulamaları bu konuda bașarısız olmaktadır. Elma köklerinin topraktan Ca iyonlarını almakta yetersiz olması, dıșarıdan Ca alınımını etkileyen toprakta Ca miktarının ve toprak pH'sının düșük olması ve Ca ile yarıș halinde olan iyonların $\left(\mathrm{K}, \mathrm{Mg}, \mathrm{NH}_{4}\right)$ fazlalığı gibi faktörlerin etkisini büyütmektedir. Kökler tarafindan alınan herhangi bir Ca iyonu ağaç içinden meyveye doğru çok yavaș hareket eder hatta ağaç büyüklüğüne bağlı olarak kök ucundan meyveye Ca'un ulașması 2-4 yıl arasında değișir. Bu yüzden Ca uygulamasından en büyük etki meyve yüzeyine uygulamadan elde edilmektedir. Daha önce de bahsedildiği gibi özellikle B eksikliği ağaç içerisinde Ca hareketini yavașlatmaktadır (Anonim, 2006). Kalsiyum alımında ağacın yașı da önemli bir faktördür. Genç ağaçlarda vejetatif gelișmenin çokluğu nedeniyle düșük Ca'u beraberinde getirir. Budama gibi așırı miktarda gelișmeyi teșvik eden uygulamalar Ca alımını olumsuz etkilemektedir. İyi bir tozlanma sonucu olușan yeterli miktardaki tohum sayısı Ca alımını etkilemektedir. Tohumlar hormonların sentezlendiği yerdir. Özellikle tohumlarda sentezlenen oksin hormonu meyveye Ca tașınmasında önemlidir (Bramlage, 1993). Buccheri ve Di Vaio (2004), yaptıkları çalıșmada tohum sayısı ile meyve ağırlığı ve meyvenin Ca içeriği arasında doğrusal ilișkiler olduğunu tespit etmișlerdir.

Hem topraktan hem yapraktan Ca uygulaması yapılabilir. Topraktan yapılacak uygulamalarda ise ülkemizde Karadeniz dıșındaki bölgelerde faydasından çok olumsuz etkileri olabilmektedir. Çünkü diğer bölgedeki topraklarımızın Ca içeriği genellikle yüksek durumdadır. Karadeniz bölgesinde de topraktan yapılan kireç veya jips uygulamaları meyvenin Ca içeriğinin arttııımasında çok az etkili olmaktadır. Bu bölgede kireç uygulanması özellikle toprakların $\mathrm{pH}$ düzeylerinin yükseltilerek Ca'un da dahil olduğu diğer besin elementlerinin alımını dolaylı sağlamaktadır.

Dilmaghani vd. (2004), meyve eti sertliği ile K:Ca oranı arasındaki ters ilișki nedeniyle kireçli topraklarda en az 8 kez yaprak gübrelemesinin gerekli olduğunu bildirmișlerdir. Kadir (2004), yaptığı çalıșmada en az 6 uygulamanın meyve ağırlığı, meyve büyüklüğü ve kırmızı renk olușumunu arttırdığını, scald olușumunu azalttığını tespit etmiștir.

Meyvenin Ca içeriğinin arttırılmasında yapraktan kimyasal uygulamalar etkili olduğu gibi yaz budamasının yapılması da meyvenin Ca içeriği üzerine olumlu etki yapacağı düșünülmektedir. Tohum anacı üzerine așilı tam verimdeki "Starkrimson Delicious" çeșidinde yapılan bu çalıșmada yaz budamasının yaprak ve meyvenin Ca içeriği üzerine etkisi araștırılmıștır.

\section{MATERYAL VE YÖNTEM}

Çalıșmada tohum anacı üzerine așilı tam verimdeki "Starkrimson Delicious" çșidi kullanıımıștır. Mayıs ayı sonlarında aynı yllın sürgünleri yakklașık $20 \mathrm{~cm}$ olduğunda yaz budaması yapıımıștır. Ağaçların iç bölgesinde çıkan tüm sürgünler el ile koparılmıștır. Temmuz ayı bașında meyveler yaklașık $70 \mathrm{~g}$ olduğunda hem yaprak hem de meyve örnekleri alınmıștır. Yaprak örnekleri ağaçların taç bölgesinde bulunan güneș gören dallar üzerinde olușmuș aynı yılın sürgünleri üzerinde olușmuș gelișmesini tamamlamıș en genç yapraklardan, meyve örnekleri ise yine ağaçların taç bölgesinde bulunan meyvelerden alınmıștır. Alınan bitki örneklerinde Ca ve diğer besin elementi analizleri yapılarak uygulamalar karșılaștııılmıștır. Bitki örnekleri önce çeșme suyunda, sonra $0.1 \mathrm{~N}$ $\mathrm{HCl}$ 'de ve daha sonra saf suda yıkanarak $65^{\circ} \mathrm{C}$ 'de sabit ağırlığa gelinceye kadar kurutulmuș ve 0.5 mm elek çapına sahip değirmende öğütülmüștür. $\mathrm{N}$ analizi için kjeldahl yaș yakma metodu, P, K, Ca ve $\mathrm{Mg}$ analizi için kuru yakma uygulanmıș ve okuma ICP-OES (Inductively Coupled Plasma Atomic Emission Spectophometer) cihazı ile yapılmıștır (Ryan vd., 2001). Yaprak analizlerinin doğruluğunu kontrol etmek için NIST marka referans elma yaprağı (1515) kullanılmıștır. İstatistik analizler için paket program (JMP) kullanılmıștır. Bu paket program ile normal dağılım analizi yapılmıș ve ekstrem değerler atılmıștır. LSD çoklu karșılaștırma testi ile uygulamalar arasındaki farklılıklar belirlenmiștir. 


\section{BULGULAR VE TARTIȘMA}

Yaz budaması yapılan ve yapılmayan uygulamaların besin elementi düzeyleri çizelge 1 ve Çizelge 2'de verilmiștir. Her bir uygulama 6 tekerrürlü olarak ve her tekerrürde 4 ağaç bulunacak șekilde yapılmıștır. Çizelgede verilen her bir değer 24 değer üzerinden hesaplanmıștır.

Sonuçlar incelendiğinde yaz budaması uygulamasının yaprakların besin elementi üzerine herhangi bir etkisinin olmadığı görülmektedir (Çizelge 1). Meyvelerde ise yaz budamasının meyvenin besin elementi içeri üzerine olumlu etkisinin olduğu yapılan analizlerle tespit edilmiștir (Çizelge 2). Yapraklarda tespit edilen N değerleri yeterlilik sınırının (\%2,45-2,85; Uçgun vd., 2013) altında bulunmuș ve uygulamalara göre istatistiksel olarak önemli bulunmamıștır. Meyvelerde ise yaz budamasının meyvenin N içeriğinin arttırdığı tespit edilmiștir. Fosfor değerleri hem yaprakta hem de meyvede uygulamalara göre farklılık göstermemiș ve yapraklarda tespit edilen $\mathrm{P}$ değerleri yeterlilik sınırının (\%0, 18-0,23; Uçgun vd., 2013) içinde yer almıștır. Yaprakların ve meyvelerin $\mathrm{K}$ değerinde uygulamalara göre farklılıklar gözlemlenirken yapraklarda var olan farklılı̆ın istatistiksel olarak önemli olmadığı meyvede ise önemli olduğu görülmektedir. Ayrıca yapraklarda tespit edilen K değerleri alt yeterlilik sınırına $(\% 1,57-1,99$; Uçgun vd., 2013) yakın olduğu tespit edilmiștir. Yaprakların Ca içeriği yaz budaması yapılan ağaçlarda \%1.29, yapılmayanlarda ise \%1,26 bulunmuș, istatistiksel olarak önemli olmamıștır ve bu değerler yeterlilik sınırı içerisinde $1 \% 1,10$ 1,41; Uçgun vd., 2013) yer almıștır. Meyvelerde ise yaz budaması yapılan ve yapılmayan ağaçların Ca içeriği sırasıyla 59,47 ve 50,86 mg 100 g-1 olduğu tespit edilmiș ve istatistiksel olarak \%1 düzeyinde önemli bulunmuștur. Tespit edilen Mg değerlerinde ise uygulamaların hem yaprakta hem de meyvede bir etkisinin olmadığı ve yaprakların Mg içeriğinin yeterlilik sınırının üzerinde $1 \% 0,32-$ 0,43; Uçgun vd., 2013) olduğu görülmüștür. Denemenin yapıldığı elma bahçesine herhangi bir Mg gübrelemesi yapılmadığı halde yapraklarda Mg seviyesinin yüksek olması toprakta bitkiler tarafından alınabilir Mg seviyesinin yüksek 1800 ppm) olması ile açıklanabilir. Ayrıca toprakların $\mathrm{pH}$ değeri $(8,10) \mathrm{Mg}$ alımı için uygun șartları olușturmaktadır.

Meyvelerin K:Ca oranları incelendiğinde yaz budaması yapılmayanlarda 22,02; yaz budaması yapılanlarda ise 17,65 olmustur. Yine meyvelerin N:Ca oranları incelendiğinde yaz budaması yapılmayan ve yapılan uygulamaların N:Ca oranları sırasıyla 9,63 ve 7,06 bulunmuștur. Yaz budaması yapılmayan uygulamalarda yüksek çıkan $N$ ve $K$ değerleri düșük çıkan Ca değerinin olumsuz etkilerini daha da arttıracağı düșünülmektedir. Drahorad (1999), özellikle K:Ca oranının acı benek olușumunda çok etkili olduğunu ve bu oranın yükselmesi ile yani Ca miktarının oransal olarak azalması ile "Acıbenek" olușumun artacağını bildirmiștir. Yine N seviyesinin yükselmesi ile oransal olarak Ca miktarının azalması ile meyvelerin diğer fizyolojik bozukluklara daha hassas olacağı bir gerçektir.

Normal gelișim șartları altında yapraktaki Ca ile $N$ arasında pozitif bir ilișki vardır. Bu ilișki transpirasyon ile hareket eden suyun sonucu olarak büyük miktarlarda Ca ve N'un ağaç içine alınması ve yapraklara tașınması ile olușur. Artan N miktarıla gelișim ve yaprak yüzeyi artacağından transpirasyonda artar. Fakat çok așırı $N$ uygulamaları yaprak/meyve oranını

Çizelge 1. Uygulamalara göre yaprakların besin elementi düzeyleri

Table 1. The level of nutrients in leaf according to application

\begin{tabular}{lccccc}
\hline Yaz Budaması & $\mathrm{N}(\%)$ & $\mathrm{P}(\%)$ & $\mathrm{K}(\%)$ & $\mathrm{Ca}(\%)$ & $\mathrm{Mg}(\%)$ \\
\hline Yok & 2,35 & 0,22 & 1,55 & 1,26 & 0,46 \\
Var & 2,34 & 0,21 & 1,49 & 1,29 & 0,46 \\
\hline
\end{tabular}

Çizelge 2. Uygulamalara göre meyvelerin besin elementi düzeyleri

Table 2. The level of nutrients in fruit according to application

\begin{tabular}{lccccc}
\hline Yaz Budaması & $\mathrm{N}(\%)$ & $\mathrm{P}(\%)$ & $\mathrm{K}(\%)$ & $\mathrm{Ca}\left(\mathrm{mg} 100 \mathrm{~g}^{-1}\right)$ & $\mathrm{Mg}\left(\mathrm{mg}^{\left.100 \mathrm{~g}^{-1}\right)}\right.$ \\
\hline Yok & $0,49^{*}$ & 0,09 & $1,12^{*}$ & 50,86 & 56,86 \\
Var & 0,42 & 0,09 & 1,05 & $59,47 * *$ & 58,86 \\
\hline
\end{tabular}


arttıracağından meyvede Ca'nın düșük olmasıyla ortaya çıan problemleri beraberinde getirir. Bu durum özellikle toprak neminin yetersiz olduğu durumlarda önemlidir. Çünkü su stresi olduğunda meyvedeki Ca, meyvedeki suyun yaprağa hareketi ile yaprağa tașınır (Hoying vd., 2004). Yumușak çekirdekli meyvelerde hasat sonrası kalitesi ile kültürel pratiklerin etkisi beraber düșünüldüğünde değișkenlerin çoğunu iki önemli ilișki açıklar. Birincisi, vejetatif gelișmeyi teșvik eden herhangi bir uygulama meyve kalitesini olumsuz etkilemektedir. Ağaçlarda mevcut Ca'un alınımı arasında meyve ve vejetatif aksam arasında șiddetli bir yarıș vardır. Vejetatif aksam bu yarıșta daha güçlü durumdadır. Bu yüzden ağaçlardaki așırı bir gelișme meyvedeki Ca konsantrasyonunu düșürmesiyle hasat sonrası meyve kalitesini azaltmaktadır. Íkincisi, meyve büyüklüğünü arttıran herhangi bir uygulama sulandırma etkisi ile meyvedeki ca miktarını oransal olarak düșüreceğinden hasat sonrası meyve kalitesini azaltmaktadır (Bramlage, 1993). Çalıșmanın sonucundan da görüleceği gibi yaz budaması yapılmayan yani vejetatif gelișmenin yüksek olduğu ağaçlardan alınan meyvelerin Ca içeriği daha düșük bulunmuștur.

\section{SONUÇLAR}

Yaz budaması yaprakların N, P, K, Ca ve Mg içeriği üzerine etkili olmazken meyvelerin $P$ ve Mg dıșındaki diğer elementler üzerine etkili bulunmuștur. Yaz budaması, meyve kalitesi ile çok yakından ilișkili olan Ca'un meyvedeki miktarını arttırmıștır. Besin elementlerinin yalnız kendi miktarlarından daha çok diğer besin elementleri ile arasındaki oranların eksiklik yada fazlalık olușmasında daha önemli olduğu bilinmektedir. Bu açıdan değerlendirildiğinde yaz budaması yapılan ağaçlardan hasat edilen meyvelerin fizyolojik bozukluklara karșı daha dayanıklı olduğu da görülmektedir. Kalsiyum eksikliğinin giderilmesinde yapraktan yapılan kimyasal gübreleme ile birlikte yaz budaması gibi kültürel uygulamaların da yapılması faydalı olacaktır.

\section{KAYNAKLAR}

Anonim (2006). Fertilizing Apples. A Guide to Fertilizing Apple Trees. Spectrum Analytic Inc. Spectrum Analytic Inc. P.O. Box639 Washington Court House, OH 43160, 1-23.

Bergmann W (1992). Nutritional Disorders of Plants. Development, Visual and Analytical Diagnosis. Gustav Fischer Verlag Jena, Stuttgart, New York, p.741.

Bramlage W J (1993). Interactions of Orchard Factors and Mineral Nutrition on Quality of Pome Fruit. Acta Hortic. (ISHS) 326: 15-28.

Buccheri M, Di Vaio C (2004). Relationship Among Seed Number, Quality, and Calcium Content in Apple Fruits. Journal of Plant Nutrition, 27(10): 1735-1746.

Dilmaghani M R, Malakouti M J, Neilsen G H, Fallahi E (2004). Interactive Effects of Potassium and Calcium on K/Ca ratio and its Consequences on Apple Fruit Quality in Calcareous Soils of Iran. Journal of Plant Nutrition, 27(7): $1149-1162$.

Drahorad W (1999). Modern Guidelines on Fruit Tree Nutrition. 42. Annual IDFTA Conference. Hamilton Ontario, Canada.

Hoying S, Fargione M, lungerman K (2004). Diagnosing Apple Tree Nutritonal Status: Leaf Analysis Interpretation and Defiency Symptoms. New York Fruit Quarterly. 12(11), 6-19.

Kacar B (1995). Bitki ve Toprağın Kimyasal Analizleri III. Ankara Üniversitesi, Ziraat Fakültesi, Eğitim Araștırma ve Geliștirme Vakfı Yayınları, No: 3, Ankara.

Kadir S A (2004). Fruit Quality at Harvest of "Jonathan" Apple Treated with Foliarly-Applied Calcium Chloride Journal of Plant Nutrition, 27(11): 1991-2006.

Neilsen G H, Neilsen D (2003). Nutritional Requirements of Apple. Apples, Botany, Production and Uses. Ed. Ferree, D. Warington, I., CAP International, Wallingford U.K.

Perring M A (2006). Lenticel Blotch Pit, Watercore, Splitting and Cracking in Relation to Calcium Concentration in the Apple Fruit. Journal of the Science of Food and Agriculture, 35 (11): 1165-1173.

Ryan J, Estafan G, Rashid A (2001). Soil and Plant Analysis Laboratory, Manual 2nd ed. ICARDA and NARS, Aleppo, Syria. 135-140 p.

Uçgun K, Gezgin S, Akgül H, Harmankaya M, Atasay A, Altındal M, İlban B, Cansu M, SeymenT (2013). ElmaAğaçlarında Yaprak Analizlerinin Değerlendirilmesinde Kullanılan Referans Değerlerlerin Isparta Bölgesi İçin Kalibrasyonu. Derim, 30 (2):54-61. 